\title{
Bees wax and its unsaponifiables as natural preservative for butter and cottonseed oils
}

\author{
By R. S. Farag (1), M. N. A. Hassan (2) and H. F. M. Ali (1) \\ 1. Biochemistry Dept., Faculty of Agriculture. Cairo University. \\ 2. Dairy Sci. and Technology Dept., Faculty of Agriculture. Cairo University. Giza - Egypt.
}

RESUMEN

Cera de abejas y su insaponificable como conservante natural para mantequilla y aceites de semilla de algodón

Sistemas modelo simples consistentes en aceite de mantequilla o aceite de semilla de algodón refinado mezclado con cera de abeja derretida y su insaponificable fueron diseñados para estudiar su rancidez oxidativa e hidrolítica durante el almacenamiento. La cera de abeja íntegra a niveles del 0,5 y $1 \%$ tuvo una actividad pro-hidrolítica significativa, mientras que su insaponificable al 0,25 y $0,5 \%$ exhibió efecto antihidrolítico sobre el aceite de mantequilla. La adición de cera de abeja íntegra al 0,5 y $1 \%$ no causó efecto sobre el índice de peróxido y ácido tiobarbitúrico del aceite de mantequilla. Sin embargo, el insaponificable de cera de abeja redujo significativamente tanto el índice de peróxido como el de ácido tiobarbitúrico de aceite de mantequilla almacenado.

El insaponificable de cera de abeja añadido al aceite de semilla de algodón refinado no tuvo efecto sobre el índice de acidez, mientras la cera de abeja íntegra mostró una actividad prohidrolítica significativa. Los valores para el índice de peróxido y ácido tiobarbitúrico del aceite de semilla de algodón refinado demostraron que tanto la cera de abeja íntegra como su insaponificable tuvieron aproximadamente la misma eficacia antioxidante. La efectividad de las sustancias añadidas sobre los productos de oxidación secundarios del aceite de semilla de algodón refinado pueden ser colocados de acuerdo con su actividad inhibitoria de la siguiente forma: BHT (200 ppm) $>$ cera de abeja $(1 \%)>$ cera de abeja $(0,5 \%)>$ insaponificable de cera de abeja $(0,5 \%)>$ insaponificable de cera de abeja $(0,25 \%)>$ control.

PALABRAS-CLAVE: Aceite de semilla de algodón - Cera de abeja Conservante - Insaponificable - Mantequilla.

\section{SUMMARY}

Bees wax and its unsaponifiables as natural preservative for butter and cottonseed oils

Simple model systems consisting of butter oil or refined cottonseed oil mixed with melted bees wax and its unsaponifiables were designated to study their hydrolytic and oxidative rancidity during storage. Whole bees wax at 0,5 and $1 \%$ levels possessed significant pro-hydrolytic activity whilst its unsaponifiables at 0,25 and $0,5 \%$ exhibited antihydrolytic effect on butter oil. The addition of whole bees wax at 0,5 and $1 \%$ caused no effect on peroxide and thiobarbituric acid values of butter oil. However, bees wax unsaponifiables significantly reduced both peroxide and thiobarbituric acid values of stored butter oil.

Bees wax unsaponifiables added to refined cottonseed oil had no effect on the acid value, whilst whole bees wax possessed significant prohydrolytic activity. The data for peroxide and thiobarbituric acid values of refined cottonseed oil demonstrated that both whole bees wax and its unsaponifiables had approximately the same antioxidant efficacy. The effectiveness of the added materials on the secondary oxidation products of refined cottonseed oil can be ranked according to its inhibition activity as follows: BHT (200 $\mathrm{ppm})>$ bees wax $(1 \%)>$ bees wax $(0,5 \%)>$ bees wax unsaponifiables $(0,5 \%)>$ bees wax unsaponifiables $(0,25 \%)>$ control.

KEY-WORDS: Bees wax - Butter - Cottonseed oil - Preservative - Unsaponifiable.

\section{INTRODUCTION}

Lipid rancidity can be classified into two main categories namely oxidative and hydrolytic rancidity. Oxidative rancidity is clearly caused by the action between the atmospheric oxygen and the unsaturated centres in lipids with the development of oxidised products which are responsible for off flavour. Hydrolytic rancidity, on the other hand, is caused by chemical or microbial hydrolysis of the triglycerides and the liberation of short-chain fatty acids which have strong off flavour. Consequently, retardation of lipid rancidity is an important element of food preservation and can be a major factor in reduction of palatability, nutritional quality and acceptability of foods (1).

Synthetic antioxidants used in food industry are phenolic compounds, e. g., butylated hydroxy toluene (BHT), butylated hydroxy anisole (BHA), butylated hydroquinone (BHQ) and propyl gallate (PG). These materials are added to foods at low concentrations (100-400 ppm) (2). Recently, there are arguments on the safety of the use of synthetic antioxidants. For instance, BHA has been reported to have toxic and carcinogenic effects (3) and BHT to cause changes in rat thyroid, stimulation of DNA synthesis and induction of enzymes (4). Also, BHT and dodecyl gallate (DDG) exhibit remarkable increase in the aflatoxin production by Aspergillus parasiticus which is known to be carcinogenic agents (5).

To date much attention has been focused on using natural antioxidants which cause no harmful effects on humans. In this respect, some essential oils, fatty alcohols, paraffin oil and others (6) (7) (8) (9) were found to exhibit antioxidant activity on cotton seed oil and an antihydrolytic action on butter. Also, the unsaponifiable matter of soybean and sesame seed oil acted as antioxidant (10). Many plants produce small amounts of waxes in their tissues, in their pollens and in their seeds. In desert plants, waxes provide a surface coating which retard evaporation and protect 
intracellular components from surrounding environmental conditions. Consequently, the objective of the present study was to use bees wax as a natural source to retard lipid hydrolytic and oxidative rancidity. This attempt was conducted with the assumption that waxes generally may provide chemical protection to endogenous sensitive compounds in the plants. Therefore, this work was designed to study the physico-chemical properties of bees was and to study the possibility of using bees wax and its unsaponifiables as antihydrolytic and antioxidant agent against butter oil and cottonseed oil rancidity.

\section{MATERIALS AND METHODS}

\subsection{Source of wax}

Bees wax was obtained fom the apiary of the Faculty of Agriculture, Cairo University, Giza - Egypt. It was purified by dissolving in a hot benzene, filtered and the solvent was evaporated using a rotary evaporator.

\subsection{Butter oil}

Fresh buffaloes milk was obtained from the experimental station herd, Faculty of Agriculture, Cairo University, Giza - Egypt. The milk was pasteurized and separated into cream and skim milk using an alfa laval separator. The cream was churned to obtain unsalted butter. The resultant butter was melted using moderate heat $\left(55^{\circ} \mathrm{C}\right)$ and the clear butter oil layer was carefully decanted.

\subsection{Cottonseed oil}

Refined cottonseed oil (free from antioxidants) was obtained from Cairo company for oil and soap. The oil peroxide and acid values were $3,04 \mathrm{meq} / \mathrm{kg}$ and $0,36 \mathrm{mg} \mathrm{KOH} / \mathrm{I}$ $\mathrm{g}$ oil, respectively.

\subsection{Solvents}

All solvents used throughout the whole work were analytical grade and distilled before use.

\subsection{Standard compounds}

Pure standard hydrocarbons and sterols were obtained from Sigma chemical company (England, London, Ltd). A set of standard alcohols was purchased from Supelco, I.N.C. (Bellefonte, Pennsylvania, U.S.A.). The purity of each standard compound was checked by GLC and gave one peak.

\subsection{Butylated hydroxy toluene (BHT)}

Crystalline BHT was obtained from Sigma chemical company (England, London, Ltd) and gave one spot by TLC.

\subsection{Thiobarbituric acid (TBA)}

TBA $(98 \%)$ was obtained from Aldrish chemical company Ltd, England.

\subsection{Chemical analyses}

Refractive index, melting point, acid, peroxide, ester, saponification, iodine, acetyl and hydroxyl values were determined according to the A.O.A.C. methods (11). TBA test was carried out according to the method described by Ottolenghi (12). The unsaponifiable matter components of bees wax were fractionated by TLC as described by Stahl (13). Identification and quantitative determination of fatty alcohols were conducted according to Farag et al. (7).

\subsection{Oxidation systems}

\section{a. Butter oil}

The resultant butter oil was distributed into six portions (ca $150 \mathrm{~g}$ each) in sterilized glass bottles. The first portion was served as a control. BHT was added to the second portion at a rate of $200 \mathrm{ppm}$. To the 3rd and 4th portions, whole bees wax was added at rate of $0,5 \%$ and $1 \%$, respectively. In the 5th and 6th portions, unsaponifiables of bees wax were added at a rate of $0,25 \%$ and $0,5 \%$, respectively. Control and treated samples were placed in an incubator at $60^{\circ} \mathrm{C} \pm 1^{\circ} \mathrm{C}$ to accelerate the autoxidation of butter oil (14). Samples were periodically analysed for quality assurance tests.

\section{b. Cottonseed oil}

Cottonseed oil was warmed and divided into equal portions and packaged in sterilised glass bottles. Whole bees wax and its unsaponifiables were added at the same levels as previously mentioned with butter oil. Control and treated samples were stored at room temperature $\left(32 \pm 2^{\circ} \mathrm{C}\right)$. Samples were periodically removed for chemical analyses.

\subsection{Statistical analyses}

The analysis of variance of the two factor factorial design was applied for all data under the present study according to the method outlined by Snedecor and Cochran (15). The new L.S.D. test was used to compare the significant differences between means of treatments (16).

\section{RESULTS AND DISCUSSION}

\subsection{Physical and chemical characteristics of crude} bees wax.

The most important physical and chemical characteris- 
tics of bees wax were determined and the results are shown in Table I. The results demonstrated that bees wax had a relatively low acid, iodine and saponification values. Also, the data indicate the presence of free hydroxyl groups and bees wax contained more than $50 \%$ unsaponifiable matter. These results are generally in accordance with the results of other researchers (17) (18).

\section{Table I}

Some Physical and Chemical Characteristics of Bees Wax

\begin{tabular}{lr}
\hline \multicolumn{1}{c}{ Property } & Value \\
\hline Refractive index at $60^{\circ} \mathrm{C}$ & 1.4415 \\
Melting point & $62.0^{\circ} \mathrm{C}$ \\
Acid value $(\mathrm{mg} \mathrm{KOH} / \mathrm{g}$ wax) & 0.85 \\
Ester value & 68.70 \\
Saponification number & 69.55 \\
lodine value & 7.84 \\
Peroxide value (m.eq. peroxide/kg wax) & 12.61 \\
Acetyl value & 70.00 \\
Hydroxyl value & 72.82 \\
Unsaponifiable matter (g\%) & 51.86 \\
\hline
\end{tabular}

\subsection{Physical methods for structural elucidation of} bees wax and its unsaponifiables.

Thin-layer chromatographic technique was applied for the identification of unsaponifiables of bees wax. The separation indicate the presence of hydrocarbons, alcohols and sterols. The infrared spectra of the unsaponifiables indicate the presence of primary alcoholic functional group (absorbance at $3380 \mathrm{~cm}^{-1}$ and $1020 \mathrm{~cm}^{-1}$ ). The ocurrance of $\mathrm{C}=\mathrm{C}$ was indicated by the absorbance at $1620-1660 \mathrm{~cm}^{-1}$. Methyl and methylene groups are characterized by the absorbance at 1380 and $1430 \mathrm{~cm}^{-1}$. The absorbance at $750 \mathrm{~cm}^{-1}$ is an indicative of the presence of long-chain hydrocarbons of 5 or more methylene groups in a straight chain.

\subsection{Fractionation of fatty alcohols in the unsaponi-} fiables by GLC.

The fatty alcohols of bees wax were fractionated into 15 components (Table II). For simplicity, the fatty alcohol levels were divided into three classes, i.e., trace $(<1 \%)$, minor $(>1-10 \%)$ and major (>10\%) components. The fatty alcohol profile of bees wax unsaponifiables was characterised by having 18:0, 19:0 and 21:0 as trace components. The fatty alcohols with 20:0, 22:0, 23:0, 24:0, 25:0, 26:0 were present as minor constituents where as 27:0, 28:0, $30: 0,31: 0$ and 32:0 were present as major substances. One single unsaturated fatty alcohol containing $\mathrm{C} 30$ was identified and present as minor constituent $(7,9 \%)$.
Table II

Fatty Alcohol Composition of Bees Wax Unsaponifiable Matter

\begin{tabular}{llr}
\hline \multicolumn{1}{c}{ Component } & \multicolumn{1}{c}{$\%$} \\
\hline n-octadecanol & $(18: 0)$ & 0.58 \\
n-nonadecanol & $(19: 0)$ & 0.15 \\
n-eicosanol & $(20: 0)$ & 2.29 \\
n-hencosanol & $(21: 0)$ & 0.81 \\
n-docosanol & $(22: 0)$ & 1.84 \\
n-tricosanol & $(23: 0)$ & 3.15 \\
n-tetracosanol & $(24: 0)$ & 1.23 \\
n-pentacosanol & $(25: 0)$ & 5.73 \\
n-hexacosanol & $(26: 0)$ & 1.70 \\
n-heptacosanol & $(27: 0)$ & 14.76 \\
n-octacosanol & $(28: 0)$ & 21.84 \\
n-triacontenol & $(30: 1)$ & 7.90 \\
n-triacontanol & $(30: 0)$ & 13.65 \\
n-hentriacontanol & $(31: 0)$ & 14.22 \\
n-dotriacontanol & $(32: 0)$ & 10.15 \\
\hline
\end{tabular}

\subsection{Effect of bees wax and its unsaponifiables on} lipid rancidity.

In the present study simple model systems consisting of butter oil or refined cottonseed oil mixed with melted bees wax and its unsaponifiables were designated to study their hydrolytic and oxidative rancidity during storage. It has been reported that the powerful synthetic antioxidants such as $\mathrm{BHT}$ and $\mathrm{BHA}$ are added to food products in the range of 100-400 ppm (2). Since bees wax did not contain a phenolic structure in its moiety which is basically responsible for the antihydrolytic and antioxidant behaviour, it was suggested to add high levels from this natural material $(0,5 \%$ and $1 \%$ for whole bees wax and $0,25 \%$ and $0,5 \%$ for the unsaponifiables) to butter oil and refined cottonseed oil.

Experiments were conducted using BHT at 200 ppm along with other experiments in order to compare the antioxidative ability of whole bees was and its unsaponifiables towards butter and refined cottonseed oils rancidity. Since the degree of unsaturation of butter oil is relatively low (I.V. $=39$ ) when compared with cottonseed oil (I.V. = 109) a high storage temperature $\left(60 \pm 1^{\circ} \mathrm{C}\right)$ was chosen to accelerate the rate of butter oil oxidation (14). The experimental period was terminated ( 21 and 16 days for butter oil and refined cottonseed oil, respectively) when an objectionable odour and high lipid rancidity values were obtained with the samples.

\subsection{Butter oil system.}

Data in Table III show the acid value (AV) for butter oil mixed with whole bees wax, bees unsaponifiables and BHT during storage. The AV results indicate that whole bees wax at 0,5 and $1 \%$ levels possessed a significant prohydrolytic activity. On the contrary, beex wax unsaponifiables exhibited antihydrolytic effect. Figs. 1 and 2 show the changes in peroxide values (PV) of butter oil mixed, with 
Table III

Acid Value for Butter Oil Mixed with Whole Bees Wax, Bees Wax Unsaponifiables and BHT During Storage

\begin{tabular}{|c|c|c|c|c|c|c|c|c|c|}
\hline \multirow{2}{*}{ Model system } & Storage & period & (day) & & & & & & \multirow{2}{*}{ Mean } \\
\hline & 0 & 3 & 6 & 9 & 12 & 15 & 18 & 21 & \\
\hline Butter oil (control) & 0.25 & 0.34 & 0.34 & 0.34 & 0.36 & 0.43 & 0.43 & 0.84 & 0.42 \\
\hline Butter oil + BHT (200 ppm) & 0.29 & 0.30 & 0.31 & 0.31 & 0.31 & 0.31 & 0.31 & 0.31 & 0.31 \\
\hline Butter oil + Bees wax $(0.5 \%, w / w)$ & 0.35 & 0.39 & 0.46 & 0.46 & 0.46 & 0.46 & 0.54 & 0.79 & 0.49 \\
\hline Butter oil + Bees wax $(1 \%, w / w)$ & 0.45 & 0.53 & 0.60 & 0.60 & 0.60 & 0.60 & 0.67 & 0.84 & 0.61 \\
\hline \multicolumn{10}{|l|}{ Butter oil + Bees wax unsaponifiables } \\
\hline$(0.25 \%, w / w)$ & 0.23 & 0.29 & 0.33 & 0.37 & 0.38 & 0.38 & 0.38 & 0.44 & 0.35 \\
\hline \multicolumn{10}{|l|}{ Butter oil + Bees wax unsaponifiables } \\
\hline$(0.5 \%, w / w)$ & 0.24 & 0.34 & 0.38 & 0.38 & 0.38 & 0.40 & 0.40 & 0.50 & 0.38 \\
\hline
\end{tabular}

Acid value is expressed as $\mathrm{mg} \mathrm{KOH} / 1 \mathrm{~g}$ butter oil.

New L.S.D. value for acid value between treatments at $p=0.05$ was 0.036 .

either bees wax, bees wax unsaponifiables or BHT during storage at $60 \pm 1{ }^{\circ} \mathrm{C}$. The effect of added substances to butter oil has shown a feature of an autocatalytic chain reaction, i.e., the rate of hydroperoxide formation increased with time. The changes in PV for butter oil (control) and butter oil mixed with different additives were very low at zero time and gradually increased with storage. BHT significantly lowered the PV of butter oil when compared with other treatments. The addition of whole bees wax $0,5 \%$ and $1 \%(w / w)$ possessed no activity on butter oil oxidation while the addition of bees wax unsaponifiables exhibited an antioxidant activity since it significantly lowered the PV of butter oil when compared with the control experiment. No significant differences were found between bees wax unsa-

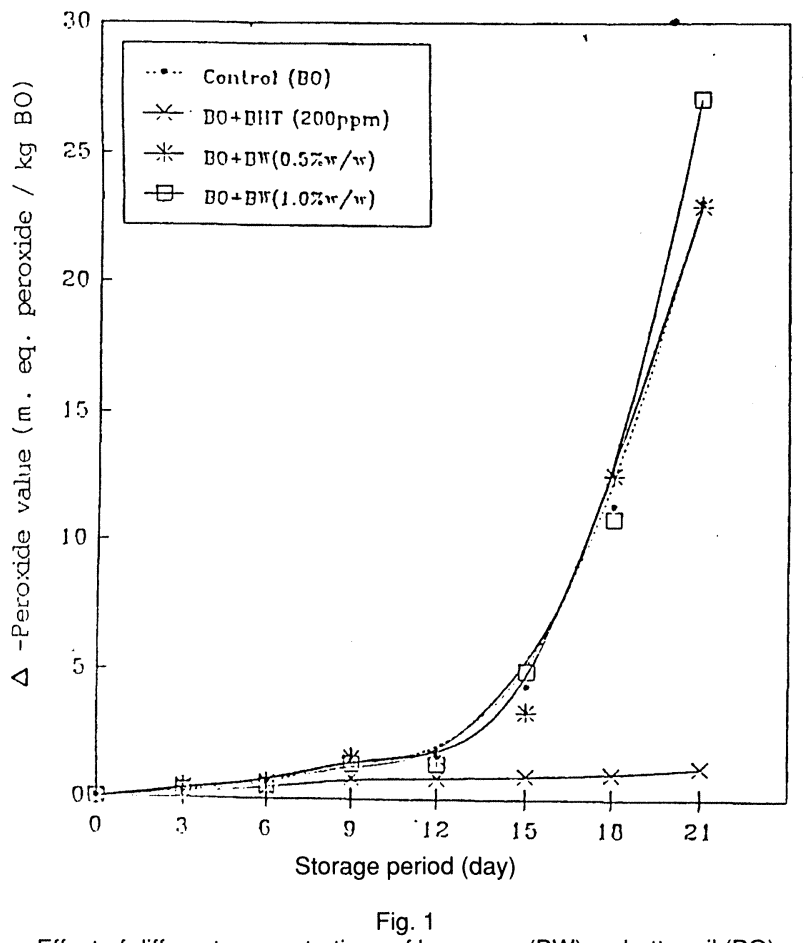

Effect of different concentrations of bees wax (BW) on butter oil (BO) oxidative rancidity during storage ponifiables at both levels $(0,25 \%$ and $0,5 \%)$ on butter oil oxidative rancidity. Hence, the low concentration of unsaponifiables is recommended for use from the economical point of view. It is worth mentioning that bees wax unsaponifiables produced moderate antioxidant power compared to that produced by BHT. Since synthetic antioxidants caused deleterious effects on human health, the natural antioxidants which possess moderate antioxidant activity are preferred over the synthetic ones to minimize the adverse effect on human being.

Figs. 3 and 4 present the changes in the secondary oxidation products of butter oil as a result of the addition of bees wax and its unsaponifiables. The addition of $\mathrm{BHT}$ at $200 \mathrm{ppm}$ to butter oil caused a very low and linear increase

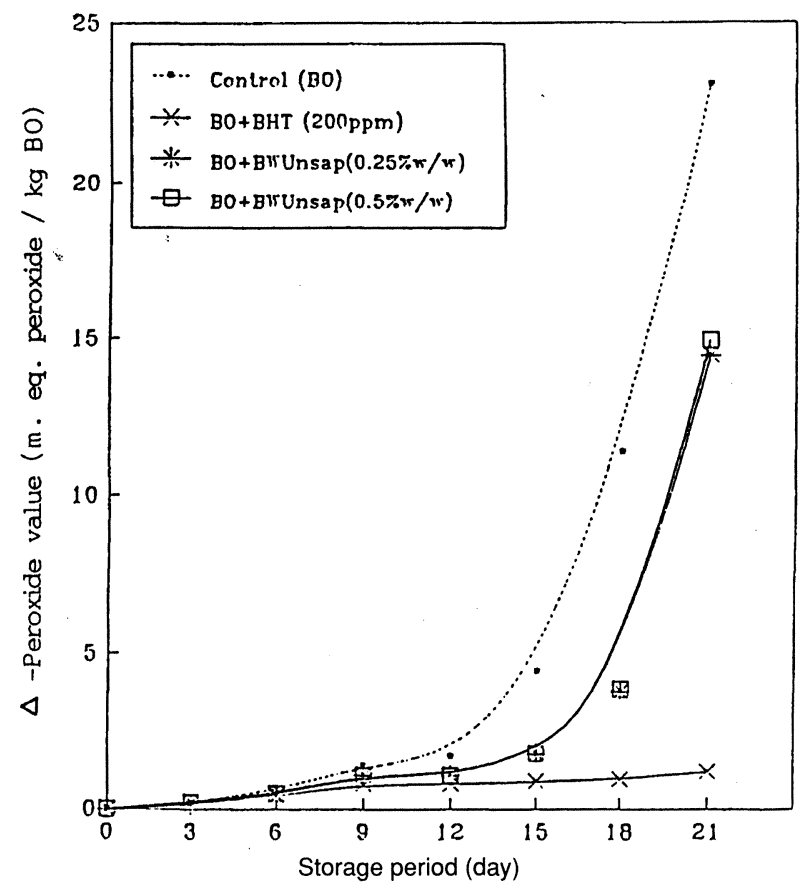

Fig. 2

Effect of different concentrations of bees wax unsaponifiables (BW Unsap) on butter oil (BO) oxidative rancidity during storage 


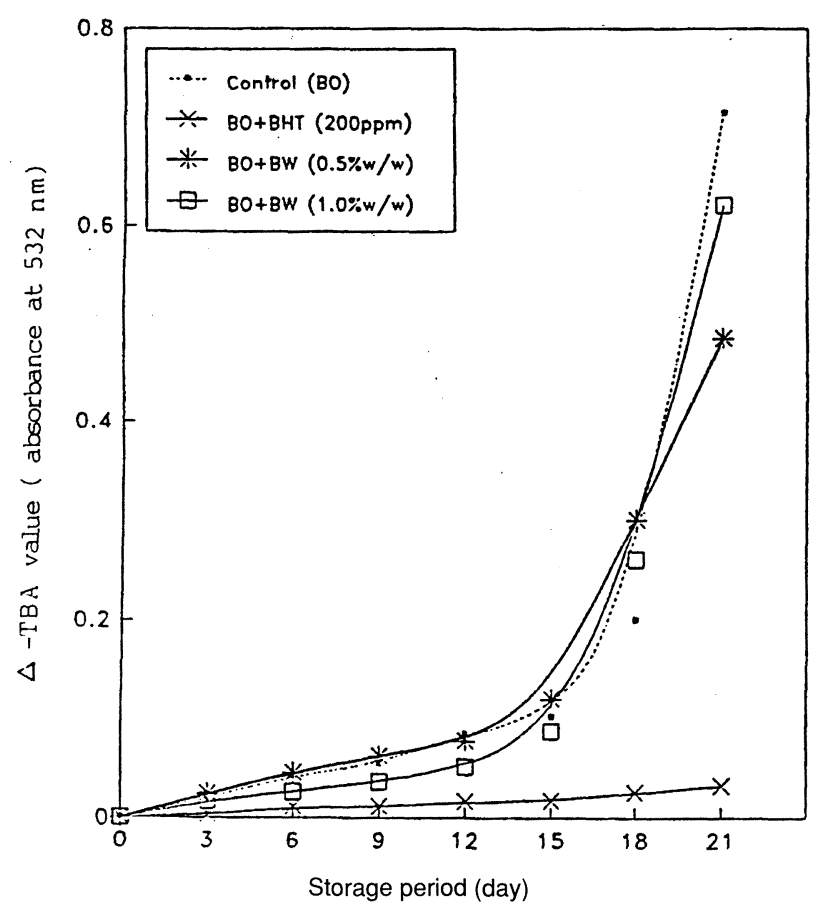

Fig. 3

Effect of different concentrations of bees wax (BW) on butter oil (BO) secondary oxidation products

of TBA values over time. On the other hand, the control and the systems containing whole bees wax at $0,5 \%$ and $1 \%$ possessed non-linear increase in TBA values during storage. In general, whole bees wax at both levels did not significantly alter the formation of secondary oxidation products in comparison with the control experiment. The addition of bees wax unsaponifiables at $0,25 \%$ and $0,5 \%$ significantly reduced the formation of the secondary oxidation products compared with the control experiment. It is worth mentioning that the high level of bees wax unsaponifiables significantly decreased the TBA values of butter oil in comparison with the low level. Generally speaking, these results coincided with the previous findings with peroxide value.

The inhibitory effect of synthetic antioxidants has been attributed to their donation of electrons or hydrogen atoms from the phenolic hydroxyl groups to oil containing free radicals and to the formation of stable free radicals which do not initiate or propagate further oxidation of oils (6). The main constituent of bees wax unsaponifiables were the straight chain saturated and unsaturated alcohols with the carbon atoms in the range of $\mathrm{C} 18-\mathrm{C} 32$. It is well known that the $\mathrm{OH}$ group is highly reactive and easily forms hydrogen bond with the active sites of hydrolytic enzymes.

An experiment was conducted where ethanol (1\%,w/w) was mixed with butter oil and the rancidity was followed by measuring A.V. and P.V. during storage. The results show that ethanol significantly lowered the increase in the A.V. of butter oil and caused non-significant effect on P.V. Consequently, one would assume that any organic compound containing $\mathrm{OH}$ group may possess an antihydrolytic activity. This hypothesis will of course depends on the $\mathrm{C}: \mathrm{OH}$ ratio. In the lower alcohol, the hydroxyl group constitutes a large

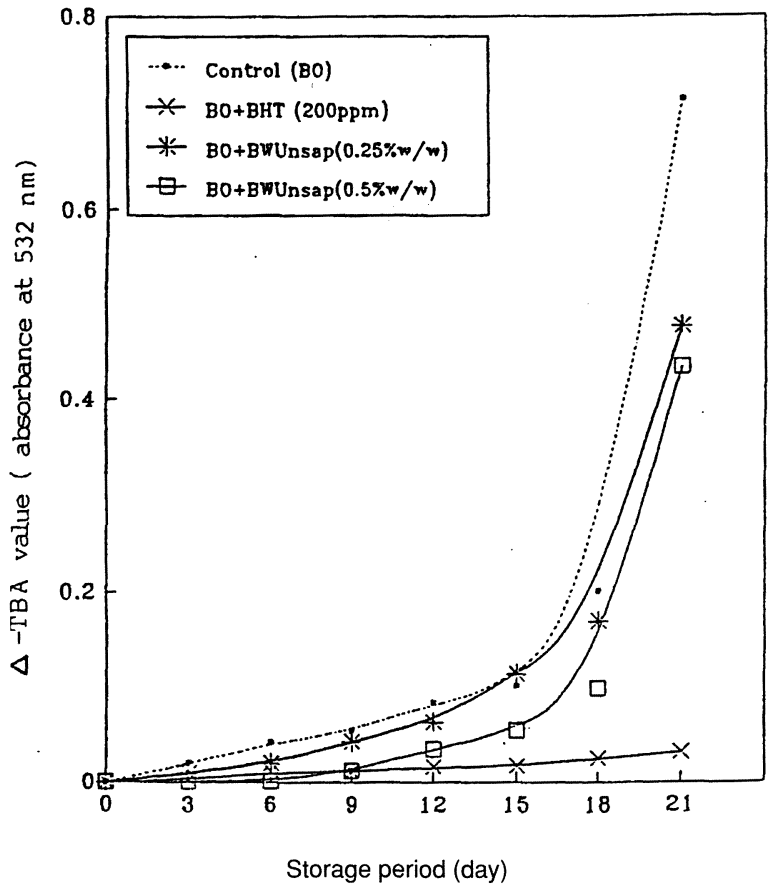

Fig. 4

Effect of different concentrations of bees wax unsaponifiables (BW Unsap) on butter oil $(\mathrm{BO})$ secondary oxidation products

part of the molecule and suppresses the enzyme activity. Conversely, as the molecular weight of the alcohol increases, the hydrophobic character of the molecule increases and hence, the influence of $\mathrm{OH}$ group is no longer predominant. The results of the present work indicate that bees wax unsaponifiables caused moderate effect on preventing butter oil hydrolytic rancidity due to low $\mathrm{OH}: \mathrm{C}$ ratio.

It appears that there is a relationship between the antioxidant efficiency and the chemical composition of the whole bees wax and its unsaponifiables. The moderate antioxidant activity of bees wax unsaponifiables might be stem from the presence of long chain fatty alcohols due to its protective effect. The hydrophobic side chains of fatty alcohols are supposed to interact with the unsaturated moiety of unsaturated fatty acids of butter oil and exhibit the antioxidative activity. As to whole bees wax, on the other hand, the structure is quite different since it mainly consists of esters of long chains alcohols and fatty acids. In this respect, Osawa and Namiki (19) established a relationship between the antioxidant activity and structure of different kinds of B-diketone analogues isolated from Eucalyptus leaf waxes. Strong antioxidative activity was observed in ntritriacontane-16,18-dione. However acetyl acetone, the simplest B-diketone, had no antioxidative activity. Long hydrocarbon side chains on both sides of B-diketones seem to be essential for antioxidative activity. Although, the minimum hydrocarbon lenght for revealing the antioxidative activity is not known.

\subsection{Cottonseed oil system.}

Table IV shows the acid values (A.V.) for cottonseed oil 


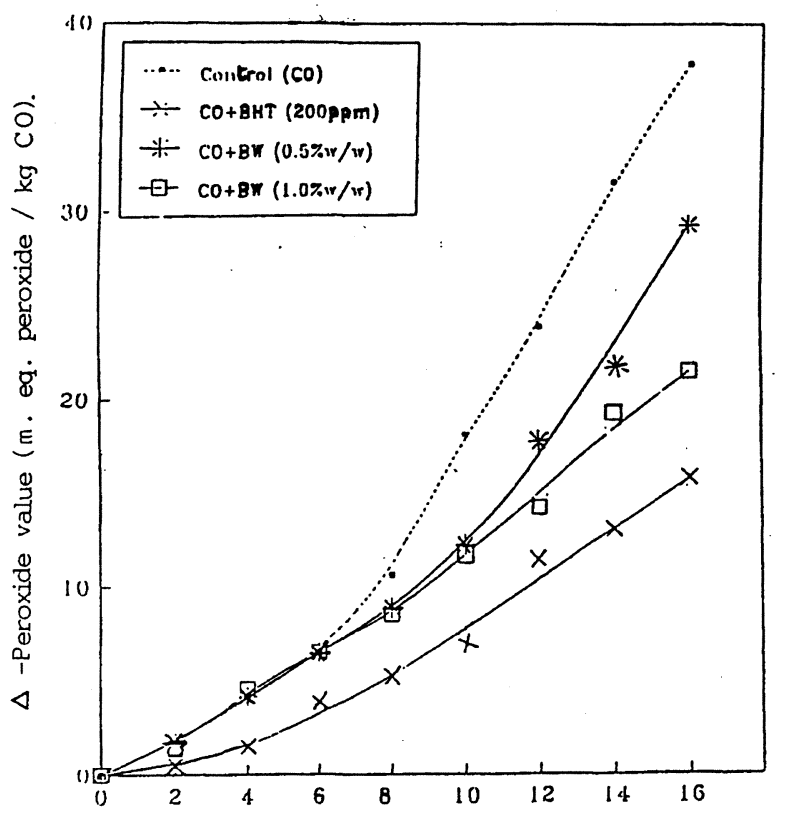

Storage period (day)

Fig. 5

Effect of different concentrations of bees wax (BW) on cottonseed oil (CO) oxidative rancidity during storage

mixed with BHT, bees wax and its unsaponifiables. The A.V. of cottonseed oil was very low and gradually increased with storage in all systems. Statistical analysis revealed that BHT and bees wax unsaponifiables added to refined cottonseed oil had no effect on the A.V. in comparison with the control experiment. Whilst, bees wax added to refined cottonseed oil possessed significant pro-hydrolytic activity. Changes in peroxide value (P.V.) of refined cotton seed oil catalysed by $\mathrm{BHT}(200 \mathrm{ppm})$, bees wax at 0,5 and $1 \%$ $(\mathrm{w} / \mathrm{w})$ and unsaponifiables at 0,25 and $0,5 \%(\mathrm{w} / \mathrm{w})$ during storage are shown in Figs. 5 and 6, respectively. In order to compare the antioxidant efficacy of bees wax and bees wax unsaponifiables at different concentrations, a P.V. of 15 was chosen since all these systems showed different oxidation patterns during the incubation period. From Figs. 5

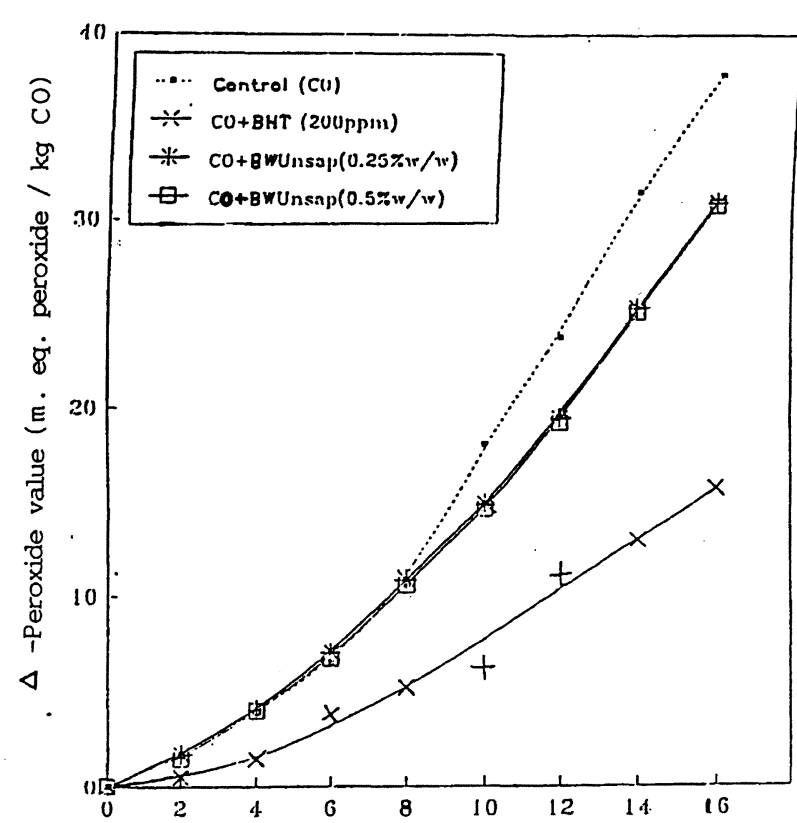

Storage period (day)

Fig. 6

Effect of different concentrations of bees wax unsaponifiables (BW Unsap) on cottonseed oil (CO) oxidative rancidity during storage

and 6 , it was found that the time required for all systems to produce a P.V. of 15 were 11,12 and 10,10 days for bees wax at 0,5 and $1 \%$ and its unsaponifiables at 0,25 and $0,5 \%$, respectively. This means that both whole bees wax and its unsaponifiables possessed approximately the same antioxidant effect on refined cottonseed oil. Hence, the protection hypothesis would be responsible for suppressing the oxidative rancidity of cottonseed oil rather than the $\mathrm{C}: \mathrm{OH}$ hypothesis. Figs. 7 and 8 show the changes in TBA values for the systems consisting of refined cottonseed oil (control) and oil containing BHT (200 ppm), bees wax at $0,5 \%$ and $1 \%(\mathrm{w} / \mathrm{w})$ and its unsaponifiables at $0,25 \%$ and $0,5 \%$. The data indicate that TBA values were gradually and linearly increased with storage in all cases. In order to envisage the effect of both bees wax and its unsaponifia-

Table IV

\section{Acid Value for Cottonseed Oil Mixed with Whole Bees Wax, Bees Wax Unsaponifiables and BHT During Storage}

\begin{tabular}{|c|c|c|c|c|c|c|c|c|c|c|}
\hline \multirow{2}{*}{ Model system } & \multicolumn{2}{|c|}{ Storage period } & \multicolumn{7}{|l|}{ (day) } & \multirow{2}{*}{ Mean } \\
\hline & 0 & 2 & 4 & 6 & 8 & 10 & 12 & 14 & 16 & \\
\hline Cottonseed oil (control) & 0.35 & 0.35 & 0.35 & 0.43 & 0.43 & 0.47 & 0.61 & 0.62 & 0.59 & 0.47 \\
\hline Cottonseed oil + BHT (200 ppm) & 0.34 & 0.35 & 0.35 & 0.40 & 0.43 & 0.45 & 0.52 & 0.52 & 0.52 & 0.43 \\
\hline Cottonseed oil + Bees wax $(0.5 \%, w / w)$ & 0.43 & 0.49 & 0.52 & 0.53 & 0.61 & 0.61 & 0.63 & 0.69 & 0.69 & 0.58 \\
\hline Cottonseed oil + Bees wax $(1 \%, w / w)$ & 0.52 & 0.54 & 0.55 & 0.58 & 0.59 & 0.61 & 0.66 & 0.73 & 0.83 & 0.62 \\
\hline \multicolumn{11}{|l|}{ Cottonseed oil + Bees wax unsaponifiables } \\
\hline$(0.25 \%, w / w)$ & 0.33 & 0.38 & 0.35 & 0.40 & 0.50 & 0.51 & 0.61 & 0.60 & 0.60 & 0.48 \\
\hline \multicolumn{11}{|l|}{ Cottonseed oil + Bees wax unsaponifiables } \\
\hline$(0.5 \%, w / w)$ & 0.34 & 0.34 & 0.34 & 0.43 & 0.47 & 0.52 & 0.52 & 0.58 & 0.58 & 0.45 \\
\hline
\end{tabular}

Acid value is expressed as $\mathrm{mg} \mathrm{KOH} / 1 \mathrm{~g}$ cottonseed oil.

New L.S.D. value for acid values between treatments at $p=0.05$ was 0.039 . 


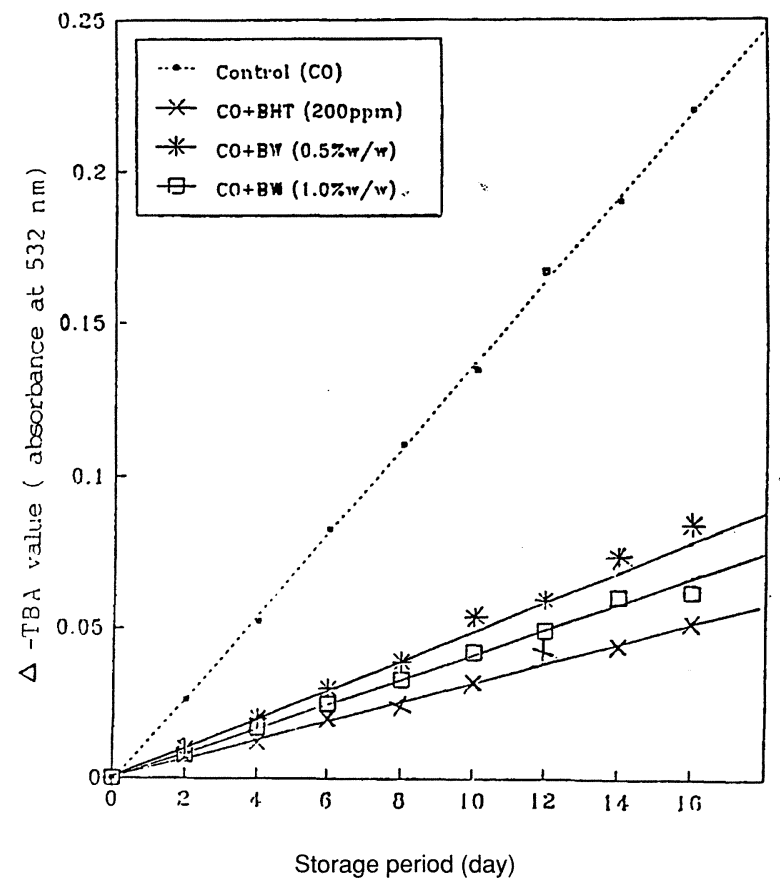

Fig. 7

Effect of different concentrations of bees wax (BW) on cottonseed oil (CO) secondary oxidation products

bles at different levels on TBA reaction reactivity, the slope values were used as means for comparison since all these systems exhibited linear increase. The slope values for the secondary oxidation rates of the systems containing refined cottonseed oil and the oil catalysed by BHT, bees wax at 0,5 and $1 \%$ and bees wax unsaponifiables at 0,25 and $0,5 \%$ were $1,1,0,26,0,41,0,34,0,83$ and 0,74 , respectively. From the aforementioned calculated values, the catalytic effectiveness of the added materials can be ranked according to its inhibition as follows: BHT (200 ppm) $>$ bees wax $(1 \%)>$ bees wax $(0,5 \%)>$ bees wax unsaponifiables $(0,5 \%)>$ bees wax unsaponifiables $(0,25 \%)>$ control.

\section{REFERENCES}

1. Fox, P.F. (1983).-«Development in dairy chemistry 2".-Applied Science Publishers, London and New York, p. 241.

2. Allen, J.C. and Hamilton, R.J. (1983).-«Rancidity in Foods».-Applied Science Publishers, London and New York, p. 21.

3. Johnson, L.E. and Cort, W.M. (1985).-«Comparison of alternative antioxidant to BHA in Citrus oil».-Beverages 148, 10.

4. Wurtzen, G., Olsen, P. and Poulson, E. (1986).-«The antioxidant butylated hydroxy toluene (BHT). A review of its toxicology and assessment of its safety in use".-Food Sci. Technol. 18, 2T 18.

5. Farag, R.S., Daw, Z.Y., Higazy, A. and Rashed, F.M. (1989).-«Effect of some antioxidants on the growth of different fungi in a synthetic medium".-Chem. Mikrobiol. Technol. Lebensm. 12, 81-85.

6. Farag, R.S., Badei, A.Z.M.A. and El-Baroty, G.S.A. (1989).-«Influence of thyme and clove essential oils on cottonseed oil oxidation".-J. Am. Oil Chemists'Soc. 66, 800-804.

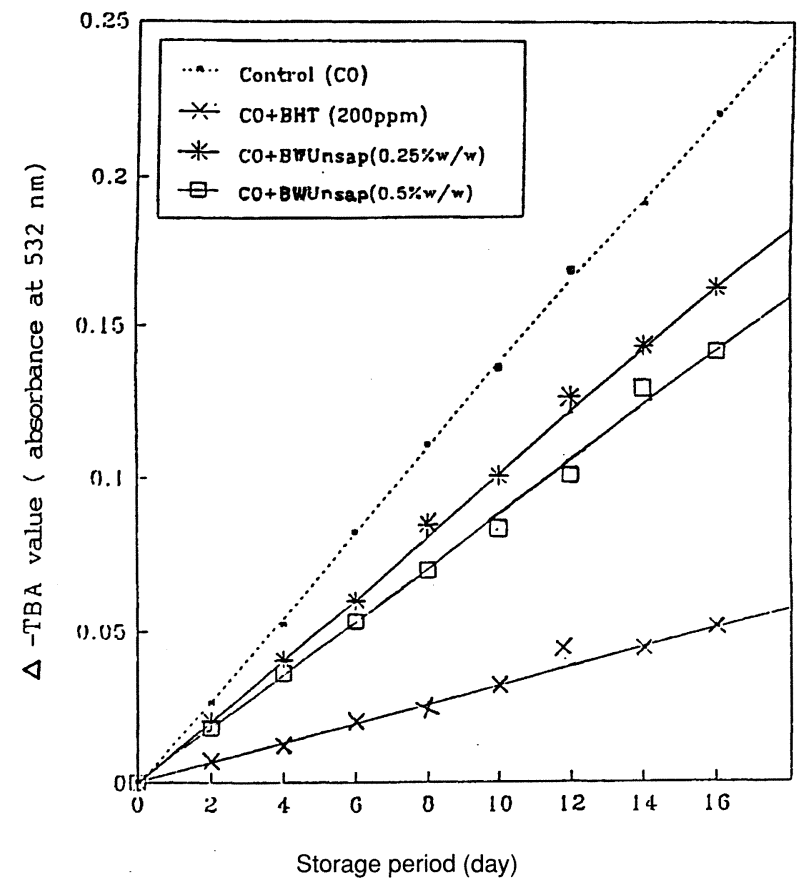

Fig. 8

Effect of different concentrations of bees wax unsaponifiables (BW Unsap) on cottonseed oil ( $\mathrm{CO}$ ) secondary oxidation products

7. Farag, R.S., Hassan, M.N.A., El-Baroty, G.S.A. and Abd El-Aziz, N.M. (1991).- «Influence of jojoba fatty alcohols on butter and refined cottonseed oil rancidity".-Chem. Mikrobiol. Technol. Lebensm. 13, 7-14.

8. Farag, R.S., El-Baroty, G.S.A. and Abdel-Latif, M.S. (1990).-«Influence of paraffin oil on lipid rancidity".-Grasas y Aceites 41, 248-255.

9. Farag, R.S., Ghali, Y and Rashed, M.M. (1982).-«Linoleic acid oxidation catalysed by Amadori compounds in aqueous media".-Can. Inst. Food Sci. Technol. 15, 174-179.

10. El-Wakeil, F., Khairy, M.S., Farag, R.S. and Hallabo, S.A.S. (1978)."The antioxidant effect of naturally occurring unsaponifiable matter on linoleic acid and some vegetable oils».-Grasas y Aceites 29, 9-15.

11. Official Methods of Analysis of the Association of Official Analytical Chemists (1975).-15th edn.-Edited by W. Horowitz, AOAC, Washington, DC.

12. Ottolenghi, A. (1959).-«Interaction of ascorbic acid and mitochondrial lipids".-Arch. Biochem. Biophys. 79, 355-363.

13. Stahl, E. (1969).-«Thin-layer chromatography. A Laboratory Handbook».-2nd edn.-Springer-Verlag, Berlín, Heidelberg, New York.

14. Thampson, S.W. (1960).-«Survey of accelerated test for determining the stability of oils and fats. Laboratory handbook for oil and fat analysis".Edited by L.V. Cooks and C. Van Rede, Academic Press, London, New York.

15. Snedecor, C.W. and Cochran, W.C. (1973).-«Statistical Methods».-6th edn.-lowa State University Press, Ames, lowa, U.S.A.

16. Waller, R.A. and Duncan, D.B. (1969).-«A bays rule for symmetric multiple comparison problem».-Amer. State Assoc. J., pp 1485-1503.

17. Tulloch, A.P. and Hoffman, L.L. (1972).-«Canadian bees wax: Analytical values and composition of hydrocarbons, free acids and long chain esters".-J. Am. Oil Chemists'Soc. 49, 696-699.

18. Tulloch, A.P. (1980).-«Bees wax: composition and analysis».-Bee world 61, 47-62.

19. Osawa, T. and Namiki, M. (1985).-«Natural antioxidants isolated from Eucalyptus leaf waxes".-J. Agric. Food Chem. 33, 777-780. 